\title{
Impelementasi Kebijakan Pemerintah dalam Mengoptimalkan Kinerja Pegawai Negeri Sipil untuk Meningkatkan Kualitas Pelayanan Jaminan Kesehatan Nasional-Badan Penyelenggara Jaminan Sosial Kesehatan
}

\author{
Aloi Kamarasyid \\ STAIN Syaikh Abdurrahman Siddik Bangka Belitung, Indonesia \\ Aloi_kamarasyid@yahoo.com
}

\begin{abstract}
The program of government is ruled by an organization which is pointed out to perform as the first target. But there are not programs of government has not been maximumly ruled by the organization which is pointed. The program of guarantee of national health of the board of social guarantee at The Common Hospital of South Bangka Hospital, Regional Hospital of Pangkalpinang, Bhakti Timah Hospital Pangkalpinang hasn't succeeded maximum. It is caused by the medical workers haven't been suitable, the sum of doctors are not enough, the facilities haven't been enough, a few of socialisations about the programs. It is needed the policy of the government to manage the programs so the service of heath can be touched for all people of South Bangka, Pangkalpinang according to the law of Republic of Indonesia number 24 in the year 2011, the regulation of minister of the heath of Republic of Indonesia number 28 in the year 2014. The policy of government is influenced by four of communication factors, human resource, disposition, and bureaucratic structure, whereas the work of civil government officers to give a service of guarantee of national health, the board of social guarantee at The Common Hospital of South Bangka, The Regional Hospital of Pangkalping, and The Bhakti Timah Hospital hasn't been ability, motivation, and maximum chance. The utility of the writing to see the work of civil government officers in giving a service of national guarantee, the board of social guarantee.
\end{abstract}

Keywords; policy of government, works of officer, the health guarantee

\begin{abstract}
Abstrak
Program pemerintah dilaksanakan oleh organisasi yang ditunjuk untuk melaksanakannya sesuai dengan target awalnya. Tetapi tidak sedikit program pemerintah belum maksimal dilaksanakan oleh organisasi yang ditunjuk itu. Program Jaminan Kesehatan Nasional-Badan Penyelenggara Jaminan Sosial Kesehatan di Rumah Sakit Umum Daerah Bangka Selatan, Rumah Sakit Umum Daerah Pangkalpinang, Rumah Sakit Bhakti Timah Pangkalpinang belum berhasil dengan maksimal. Disebabkan oleh tenaga medis yang belum sesuai, jumlah dokter tidak memadai, fasilitas kurang memadai dan tidak lengkap, kurangnya sosialisasi tentang program tersebut. Untuk itu diperlukan kebijakan pemerintah yang mengatur program tersebut sehingga pelayanan kesehatan bisa tersentuh bagi semua lapisan masyarakat Bangka Selatan, Pangkalpinang, sesuai dengan Undang-Undang Republik Indonesia Nomor 24 Tahun 2011, Peraturan Menteri Kesehatan Republik Indonesia Nomor 28 Tahun 2014. Kebijakan pemerintah itu dipengaruhi oleh empat faktor: komunikasi, sumber daya, disposisi, dan struktur birokrasi. Sedangkan kinerja pegawai negeri sipil untuk memberikan pelayanan Jaminan Kesehatan Nasional-Badan Penyelenggara Jaminan Sosial Kesehatan di Rumah Sakit Umum Daerah Bangka Selatan, Rumah Sakit Umum Daerah Pangkalpinang, Rumah Sakit Bhakti Timah Pangkalpinang belum memiliki kemampuan, motivasi, kesempatan secara maksimal. Manfaat penulisan ini: untuk melihat kinerja pegawai negeri sipil dalam memberikan pelayanan Jaminan Kesehatan Nasional-Badan Penyelenggara Jaminan Sosial Kesehatan tersebut.
\end{abstract}

Kata Kunci; kebijakan pemerintah, kinerja pegawai, jaminan kesehatan.

Received: 11-10-2017; accepted: 14-11-2017; published: 02-12-2017

Citation: Aloi Kamarasyid, 'Impelementasi Kebijakan Pemerintah dalam Mengoptimalkan Kinerja Pegawai Negeri Sipil untuk Meningkatkan Kualitas Pelayanan Jaminan Kesehatan Nasional-Badan Penyelenggara Jaminan Sosial Kesehatan', Mawa'izh, vol. 8, no. 2 (2017), pp. 275-292. 


\section{A. Pendahuluan}

etiap kegiatan yang telah ditetapkan melalui program pemerintah harus dilakukan dengan semaksimal mungkin sesuai dengan tujuan yang telah dibuat secara bersama-sama. Biasanya untuk melaksanakan program tersebut ditunjuklah atau dibentuklah sebuah organisasi yang dianggap dapat mengerjakannya sesuai dengan visi, misi, program dan target yang telah ditetapkan sebelumnya. Tetapi tidak sedikit program pemerintah belum maksimal dilaksanakan oleh organisasi yang ditunjuk itu. Salah satunya ada Program Jaminan Kesehatan Nasional-Badan Penyelenggara Jaminan Sosial Kesehatan di Rumah Sakit Umum Daerah Bangka Selatan, Rumah Sakit Umum Daerah Pangkalpinang, Rumah Sakit Bhakti Timah Pangkalpinang belum dilaksanakan dengan maksimal.

Hal ini disebabkan oleh fasilitas rumah sakit yang belum memadai, jumlah kamar rawat inap ataupun jalan masih sangat kurang, tenaga medis yang belum sesuai, jumlah dokter yang tidak memadai (baik dokter umum maupun ahli), kurangnya sosialisasi tentang program tersebut, dan lain-lain. Untuk itu diperlukan adanya kebijakan pemerintah yang mengatur program tersebut sehingga Pelayanan Jaminan Kesehatan Nasional-Badan Penyelenggara Jaminan Sosial Kesehatan itu bisa tersentuh bagi semua lapisan masyarakat Bangka Selatan, Pangkalpinang dan sekitarnya, seperti Undang-Undang Republik Indonesia Nomor 24 Tahun $2011^{1}$ dan Peraturan Menteri Kesehatan Republik Indonesia Nomor 28 Tahun $2014 .^{2}$

Secara umum istilah "kebijakan" atau "policy" dipergunakan untuk menunjuk perilaku seseorang aktor (misalnya seseorang pejabat, suatu kelompok, maupun suatu lembaga pemerintah) dan sejumlah aktor dalam suatu bidang kegiatan tertentu. Pengertian seperti ini dapat kita gunakan dan relatif memadai untuk keperluan pembicaraanpembicaraan biasa, namun menjadi kurang memadai untuk pembicaraan-pembicaraan sistematis menyangkut analisis kebijakan publik. ${ }^{3}$

Istilah kebijaksanaan atau kebijakan yang diterjemahkan dari kata policy memang biasanya dikaitkan dengan keputusan pemerintah, karena pemerintahlah yang mempunyai wewenang atau kekuasaan untuk mengarahkan masyarakat, dan bertanggung jawab Sosial.

1 Undang-Undang Republik Indonesia Nomor 24 Tahun 2011 Tentang Badan Penyelenggara Jaminan

2 Peraturan Menteri Kesehatan Republik Indonesia Nomor 28 Tahun 2014 Tentang Pedoman Pelaksanaan Program Jaminan Kesehatan Nasional.

${ }^{3}$ Budi Winarno, Teori dan Proses Kebijakan Publik (Yogyakarta: Media Pressindo, 2004), p. 14-5. 
melayani kepentingan umum. Ini sejalan dengan pengertian publik itu sendiri dalam bahasa Indonesia yang berarti pemerintah, masyarakat atau umum. Menurut Charles 0. Jones, istilah kebijakan (policy term) digunakan dalam praktek sehari-hari namun digunakan untuk menggantikan kegiatan atau keputusan yang sangat berbeda. Istilah ini sering dipertukarkan dengan tujuan (goals), program, keputusan (decisions), standar, proposal, dan grand desain. ${ }^{4}$

Berkaitan dengan istilah kebijakan tersebut, James E. Anderson mengartikan kebijakan sebagai berikut : “.... a purposive course of action followed an actor set of actors in dealing with a problem or matter of concern" (serangkaian tindakan yang mempunyai tujuan tertentu yang diikuti dan dilaksanakan oleh seseorang pelaku atau kelompok pelaku guna memecahkan suatu masalah tertentu). ${ }^{5}$

Implementasi kebijakan, menurut Mazmanian dan Sabatier adalah memahami apa yang seharusnya terjadi sesudah suatu program dinyatakan berlaku atau dirumuskan. Pemahaman tersebut mencakup usaha-usaha untuk mengadministrasikannya dan menimbulkan dampak nyata pada masyarakat atau kejadian-kejadian. ${ }^{6}$ Sedangkan menurut Chief H.O, kebijakan pemerintah sebagai suatu tindakan bersanksi yang mengarah pada suatu tujuan tertentu yang diarahkan pada suatu masalah atau sekelompok masalah tertentu yang saling berkaitan yang mempengaruhi sebagian besar warga masyarakat. ${ }^{7}$

Sedangkan George, C. Edwards III, merumuskan empat faktor yang merupakan syarat-syarat penting guna mengkaji dan meneliti berhasil tidaknya implementasi kebijakan. Keempat faktor itu adalah sebagai berikut:

1. Communication: Komunikasi, menyangkut penyampaian atau penyebaran informasi (Transmission), kejelasan (Clarity) dan konsistensi (Consistency) dari informasi yang disampaikan.

2. Resources: Sumber daya, menyangkut empat komponen yaitu staf (staff) yang cukup (jumlah dan mutu), informasi (Information) yang dibutuhkan guna mengambil keputusan, kewenangan (authority) yang cukup guna melaksanakan tugas dan tanggung jawabnya serta fasilitas (facilities) yang dibutuhkan dalam implementasi kebijakan.

3. Disposition: Disposisi atau sikap pelaksana (attitudes of implementers), menyangkut dampak (effects) dari kalangan aktor dalam mengimplementasikan kebijakan secara efektif, pengaturan bagi para pelaksana kebijakan, dan pemberian insentif (gaji, honor, dan sebagainya).

${ }^{4}$ Ibid, p. 14.

${ }^{5}$ M. Irfan Islamy, Prinsip-Prinsip Perumusan Kebijaksanaan Negara (Jakarta: PT. Bumi Aksara, 2004), p. 17.

${ }^{6}$ Joko Widodo, Analisis Kebijakan Publik. Konsep Dan Aplikasi Analisis Proses Kebijakan Publik (Malang: Bayumedia Publishing, 2010), p. 87.

${ }^{7}$ J.R.G Djopari, Kebijakan Pemerintahan (Jakarta: Universitas Terbuka, 2009), p .1.13. 
4. Bureaucratic structure: Struktur birokrasi, menyangkut prosedur standar operasi dalam pelaksanaan kebijakan (Standard Operating Procedures) dan pengaturan tata aliran pekerjaan dan pelaksana program. ${ }^{8}$

Sedangkan kinerja adalah istilah yang populer di dalam manajemen, yang sering disamakan dengan hasil kerja, prestasi kerja dan performance. Menurut The Sriber Bantam English Dictionary terbitan Amerika Serikat dan Canada tahun 1979 mengatakan "to perform" mempunyai beberapa "entries" berikut: (1) to do or carry out; executive, (2) to discharge or fulfill, as a vow, (3) to party, as a character in a play, (4) to render by the voice or musical instrument, (5) to execute or complete, on undertaking, (6) to act a part in a play, (7) to perform music, (8) to do what is expected of person or machine. ${ }^{9}$ Sedangkan Sadili Samsudin menyebutkan bahwa: kinerja adalah tingkat pelaksanaan tugas yang dapat dicapai seseorang, unit atau divisi dengan menggunakan kemampuan yang ada dan batasan-batasan yang telah ditetapkan untuk mencapai tujuan organisasi/ perusahaan. ${ }^{10}$

Menurut Lembaga Administrasi Negara (2000) mengatakan kinerja sebagai gambaran mengenai tingkat pencapaian pelaksanaan suatu kegiatan/program/kebijakan dalam mewujudkan sasaran, tujuan, misi, dan visi organisasi. ${ }^{11}$ Sedangkan Pegawai Negeri Sipil (pasal 1 ayat (1) Undang-Undang Nomor 43 Tahun 1999) adalah setiap Warga Negara Republik Indonesia yang telah memenuhi syarat yang telah ditentukan, diangkat oleh pejabat yang berwenang dan diserahi tugas Negara. ${ }^{12}$ Di sisi lain Robbins, yang menjadi ukuran kinerja pegawai mempertimbangkan hal-hal sebagai berikut: kemampuan, motivasi, kesempatan. ${ }^{13}$

Menurut Triguno, kualitas sebagai suatu standar yang harus dicapai oleh seseorang/ kelompok/ organisasi mengenai kualitas sumber daya manusia, kualitas cara kerja, proses dan hasil kerja atau produk yang berupa barang dan jasa. Selanjutnya dikatakan: Berkualitas mempunyai arti memuaskan kepada yang dilayani, baik internal maupun eksternal, dalam arti optimal pemenuhan atas tuntutan/ persyaratan pelanggan/ masyarakat. ${ }^{14}$ Dalam prespektif lain, Sampara Lukman mengartikan: kualitas adalah sebagai janji pelayanan agar

8 George, C, Edwards III, Implementasi Kebijakan Publik: Transpormasi Pikiran (Yogyakarta: Lukman Opset, 2003), pp. 9-12.

${ }^{9}$ Suyadi Prawirosentono, Kebijakan Kinerja Karyawan (Yogyakarta: BPFE, 1999), pp. 1-2.

10 Sadili Samsudin, Manajemen Sumber Daya Manusia (Bandung: Pustaka Setia, 2005), p. 159.

11 Mirrian Sjofyan Arif, dkk., Manajemen Pemerintahan (Jakarta: Universitas Terbuka, 2008), p. 6.3.

12 Undang-Undang Nomor 43 Tahun 1999 Tentang Pokok-Pokok Kepegawaian.

13 Stephen, P Robbins, Perilaku Organisasi, Jilid 1 dan 2, trans. by Tim Indeks. (Jakarta: PT. Indeks Kelompok Gramedia, 2008), p. 218.

14 Triguno, Budaya Kerja: Menciptakan Lingkungan yang Kondusif untuk Meningkatkan Produktifitas Kerja (Jakarta: Gulgen Trapon Press, 2002), p. 76. 
yang dilayani merasa diuntungkan. Sehingga di sini kualitas lebih berupa suatu input dalam kaitannya dengan pelayanan yang terjadi antara pihak provider dan konsumen/pelanggan dengan ketentuan apabila konsumen merasa puas dalam menikmati hasil produk tersebut, maka dapat dikatakan berkualitas atau ada kualitas. 15

Sedangkan pelayanan menurut Sugiarto merupakan suatu tindakan yang dilakukan untuk memenuhi kebutuhan orang lain (konsumen, pelanggan, tamu, klien, pasien, penumpang, dan lain-lain) pada tingkat pemuasannya hanya dapat dirasakan oleh orang yang melayani dan dilayani. ${ }^{16}$

\section{B. Implementasi Kebijakan Pemerintah Tentang Pelayanan Jaminan Kesehatan Nasional-Badan Penyelenggara Jaminan Sosial Kesehatan}

Kebutuhan akan layanan kesehatan terus meningkat, pada umumnya masalah kesehatan ini dipengaruhi berbagai faktor di antaranya: faktor urbanisasi, faktor tempat pembuangan limbah, faktor tingkat pendidikan, faktor lingkungan, faktor petugas kesehatan, faktor pelayanan kesehatan dan faktor budaya. Meningkatnya kebutuhan layanan masyarakat di berbagai bidang tentu harus di imbangi ketersediaan sumber daya manusia untuk mengatasi setiap permasalahan yang muncul dalam pemenuhannya.

Menghadapi tantangan akan layanan kebutuhan masyarakat ke depan pemerintah daerah seharusnya lebih cepat tanggap dan bereaksi dengan menguatkan potensi yang di miliki daerah untuk menghadapi tantangan masyarakat ke depan dalam pemenuhan kebutuhan pokok. Kebutuhan pokok itu tidak hanya sebatas pangan, sandang, dan papan saja, tetapi sarana dan prasarana untuk pemenuhan pangan, sandang, dan papan itu sendiri ke depan menjadi tantangan seiring meningkatnya jumlah penduduk dan kemajuan teknologi. Untuk pemerintah pusat maupun daerah harus mampu memecahkan berbagai permasalahan yang timbul dalam masyarakat, salah satu dengan cara membuat programprogram kebijakan yang beermanfaat langsung bagi seluruh rakyat tanpa terkecuali.

Program Jaminan Kesehatan Nasional-Badan Penyelenggara Jaminan Sosial (JKSBPJS) Kesehatan: adalah salah satu program pemerintah pusat sebagai sebuah program perlindungan kesehatan nasional yang dibuat oleh pemerintah pusat untuk rakyatnya tanpa terkecuali. Program ini tersebar seluruh Rumah Sakit Pemerintah (baik di pusat maupun daerah) di Indonesia berdasarkan Undang-Undang Republik Indonesia Nomor 24 Tahun 2011

${ }^{15}$ Sampara, Lukman, Manajemen Kualitas Pelayanan (Jakarta: STIA LAN Press, 2003), p. 11.

${ }^{16}$ Sugiarto, Demensi Pelayanan Sehari-hari: Kinerja Pemerintahan=Indikator yang dilupakan (akarta: LAN, 2003), p. 36. 
Tentang Badan Penyelenggara Jaminan Sosial dan Peraturan Menteri Kesehatan Republik Indonesia Nomor 28 Tahun 2014 Tentang Pedoman Pelaksanaan Program Jaminan Kesehatan Nasional. Implementasi kebijakan Program Pelayanan Jaminan Kesehatan Nasional-Badan Penyelenggara Jaminan Sosial Kesehatan di Rumah Sakit Umum Daerah Bangka Selatan, Rumah Sakit Umum Daerah Pangkalpinang, Rumah Sakit Bhakti Timah Pangkalpinang dapat dikatakan berhasil dengan cepat atau terlambatnya, seperti dikemukakan oleh George C. Edward III bahwa berhasil atau terlambatnya suatu proses implementasi dipengaruhi oleh empat faktor yaitu Komunikasi, Sumber Daya, Disposisi, dan Struktur Birokrasi.

\section{Komunikasi}

Komunikasi sangat menentukan keberhasilan pencapaian tujuan dari implementasi kebijakan pemerintah tentang Program Pelayanan Jaminan Kesehatan Nasional-Badan Penyelenggara Jaminan Sosial Kesehatan di Rumah Sakit Umum Daerah Bangka Selatan, Rumah Sakit Umum Daerah Pangkalpinang, Rumah Sakit Bhakti Timah Pangkalpinang. Efektif tidaknya implementasi kebijakan pemerintah itu apabila para pembuat keputusan sudah mengetahui apa yang harus mereka (organisasi/ lembaga) yang diberikan kewenangan untuk melaksanakan programnya sehingga tujuannya dapat dicapai secara maksimal sesuai target yang diharapkan.

Suatu program dapat dilaksanakan dengan baik oleh implementor apabila dikomunikasikan ke berbagai pihak sesuai arahan, sasaran, tujuan yang hendak dicapai. Kebijakan yang dikomunikasikan itu harus tepat, akurat, dan konsisten. Program Pelayanan Jaminan Kesehatan Nasional-Badan Penyelenggara Jaminan Sosial Kesehatan di Rumah Sakit Umum Daerah Bangka Selatan, Rumah Sakit Umum Daerah Pangkalpinang, Rumah Sakit Bhakti Timah Pangkalpinang adalah suatu program pemerintah pusat secara nasional yang bertujuan untuk meningkatkan kesehatan bagi seluruh masyarakat. Keterlibatan semua pelaksana kebijakan menjadi kunci utama keberhasilan sebuah program pemerintah.

Berdasarkan kenyataan dilapangan sosialisasi hanya dilakukan sampai tingkat perangkat saja, namun untuk ke masyarakat sangat kurang sekali, hanya masyarakat yang pernah datang berobat ke Rumah Sakit Umum Daerah Bangka Selatan, sedangkan masyarakat awam yang jauh tempat tinggalnya atau tersebar di wilayah di kelurahan, kecamatan se-Bangka Selatan banyak yang tahu keberadaan Program Pelayanan Jaminan Kesehatan Nasional-Badan Penyelenggara Jaminan Sosial Kesehatan di Rumah Sakit Umum Daerah Bangka Selatan. Komunikasi antara para implementor kebijakan harus jelas dan sampai keseluruh masyarakat tanpa terkecuali, karena jika kurang informasinya maka akan 
berdampak pada hasil program tersebut, sehingga hasilnya kurang baik. Sedangkan untuk Rumah Sakit Umum Daerah Pangkalpinang, Rumah Sakit Bhakti Timah Pangkalpinang sudah cukup baik karena wilayahnya terlalu luas dibandingkan dengan Bangka Selatan kecuali masyarakat yang datang dari luas wilayah Kota Pangkalpinang.

Berdasarkan fakta dilapangan, sosialisasi Program Pelayanan Jaminan Kesehatan Nasional-Badan Penyelenggara Jaminan Sosial Kesehatan di Rumah Sakit Umum Daerah Bangka Selatan bagi masyarakat di Bangka Selatan ternyata para implementor kebijakan tersebut kurang melakukan sosialisasi, kurang atau bahkan tidak adanya baligho, spanduk, brosur dan pengumuman yang disebarkan dan dipasangkan disetiap dusun/ desa sehingga masih banyak masyarakat awan yang tidak tahu dan mengerti tentang program pemerintah ini. Padahal sesuai dengan rencananya program ini sudah berlaku sejak tanggal 1 Januari 2014 yang lalu, tetapi kenyataannya sebagian masyarakat (awam) Bangka Selatan banyak yang belum tahu tentang Program Pelayanan Jaminan Kesehatan Nasional-Badan Penyelenggara Jaminan Sosial Kesehatan di Rumah Sakit Umum Daerah Bangka Selatan. Sedangkan untuk wilayah kota Pangkalpinang sosialisasi Program Pelayanan Jaminan Kesehatan Nasional-Badan Penyelenggara Jaminan Sosial Kesehatan di Rumah Sakit Umum Daerah Pangkalpinang, Rumah Sakit Bhakti Timah Pangkalpinang sosialisasi sudah berjalan dengan cukup baik tapi dtingkatkan lagi dan dipertahan.

\section{Sumber Daya}

Faktor sumber daya (tenaga kerja) mempunyai dampak sangat vital dalam mengimplementasikan Program Pelayanan Jaminan Kesehatan Nasional-Badan Penyelenggara Jaminan Sosial Kesehatan di Rumah Sakit Umum Daerah Bangka Selatan. Sumber daya di sini terbagi dua, yaitu: sumber daya manusia dan non-sumber daya manusia. Sumber daya manusia di sini adalah staf yang cukup, informasi, wewenang. Sedangkan nonsumber daya manusia adalah fasilitas atau sarana dan prasarana yang mendukung terlaksananya Program Pelayanan Jaminan Kesehatan Nasional-Badan Penyelenggara Jaminan Sosial Kesehatan di Rumah Sakit Umum Daerah Bangka Selatan, Rumah Sakit Umum Daerah Pangkalpinang, Rumah Sakit Bhakti Timah Pangkalpinang.

\section{Stafyang cukup (jumlah dan mutu)}

Sumber daya yang utama dalam implementasi kebijakan pemerintah adalah staf yang handal, memiliki kompetensi, dan bertanggungjawab atas pekerjaannya. Staf yang dimaksud adalah dokter, tenaga medis, perawat, bidan, dan didukung oleh tenaga kerja yang lainnya. Biasanya kegagalan yang sering terjadi dalam implementasi kebijakan Program Pelayanan 
Jaminan Kesehatan Nasional-Badan Penyelenggara Jaminan Sosial Kesehatan itu disebabkan: staf yang tidak memiliki kemampuan di bidangnya, kurangnya pengalaman, jumlah personilnya tidak mencukupi, pendidikannya kurang menunjang, dan lain-lainnya. Berdasarkan kenyataannya jumlah petugas yang melakukan Program Pelayanan Jaminan Kesehatan Nasional-Badan Penyelenggara Jaminan Sosial Kesehatan di Rumah Sakit Umum Daerah Bangka Selatan, Rumah Sakit Umum Daerah Pangkalpinang, Rumah Sakit Bhakti Timah Pangkalpinang, belum memadai, baik dari segi kualitas maupun kuantitasnya, perlu dipertanyakan kredibilitas, tanggung jawab, kemampuannya.

\section{Informasi yang dibutuhkan}

Informasi merupakan sumber penting dalam mengimplementasikan kebijakan pemerintah. Ketersedian informasi sangat mendukung pelaksanaan Program Pelayanan Jaminan Kesehatan Nasional-Badan Penyelenggara Jaminan Sosial Kesehatan di Rumah Sakit Umum Daerah Bangka Selatan. Berbagai kendala biasanya terjadi dalam melaksanakan kebijakan, salah satunya adalah pengetahuan tentang bagaimana mengimplementasikan kebijakan itu sendiri. Informasi yang dibutuhkan adalah bagaimana melaksanakan dan memperoleh Program Pelayanan Jaminan Kesehatan Nasional-Badan Penyelenggara Jaminan Sosial Kesehatan di Rumah Sakit Umum Daerah Bangka Selatan, Rumah Sakit Umum Daerah Pangkalpinang, Rumah Sakit Bhakti Timah Pangkalpinang apakah sesuai dengan Undang-Undang Republik Indonesia Nomor 24 Tahun 2011 dan Peraturan Menteri Kesehatan Republik Indonesia Nomor 28 Tahun 2014, bagaimana kepatuhan dari para pelaksana terhadap ketentuan yang mengaturnya.

Berdasarkan kenyataannya; masih banyak keluhan masyarakat terlebih-lebih bagi masyarakat awam yang ingin memperoleh Program Pelayanan Jaminan Kesehatan Nasional-Badan Penyelenggara Jaminan Sosial Kesehatan di Rumah Sakit Umum Daerah Bangka Selatan, Rumah Sakit Umum Daerah Pangkalpinang, Rumah Sakit Bhakti Timah Pangkalpinang, karena yang datang berobat ke Pangkalpinang juga banyak dari daerah lain, seperti dari Bangka Selatan, Bangka Tengah, dan Bangka serta tidak sedikit datang dari Bangka Barat.

\section{Kewenangan.}

Kewenangan itu harus bersifat formal agar kebijakan dapat diimplementasikan dengan benar sesuai Undang-Undang Republik Indonesia Nomor 24 Tahun 2011 dan Peraturan Menteri Kesehatan Republik Indonesia Nomor 28 Tahun 2014. Kewenangan itu merupakan legitimasi bagi para implementor untuk melaksanakan program tersebut. Kewenangan yang 
dimiliki para implementor adalah melayani warga masyarakat yang menerima bantuan Program Pelayanan Jaminan Kesehatan Nasional-Badan Penyelenggara Jaminan Sosial Kesehatan di Rumah Sakit Umum Daerah Bangka Selatan, Rumah Sakit Umum Daerah Pangkalpinang, Rumah Sakit Bhakti Timah Pangkalpinang, jangan disia-siakan mereka yang memperoleh jaminan kesehatan dari pemerintah.

\section{Sarana yang dibutuhkan}

Sarana merupakan alat yang mendukung implementasi kebijakan agar dapat mencapai tujuannya. Dalam melaksanakan Program Pelayanan Jaminan Kesehatan Nasional-Badan Penyelenggara Jaminan Sosial Kesehatan di Rumah Sakit Umum Daerah Bangka Selatan, Rumah Sakit Umum Daerah Pangkalpinang, Rumah Sakit Bhakti Timah Pangkalpinang tentu diperlukan berbagai sarana dan prasarana seperti fasilitas rumah sakit, ruang rawat inap, ruang gawat darurat, instalasi gawat darurat, ruang tunggu, ruang pemeriksaan, kendaraan dinas, fasilitas lainnya untuk menunjang proses implementasi Program Pelayanan Jaminan Kesehatan Nasional-Badan Penyelenggara Jaminan Sosial Kesehatan tersebut, sehingga hasilnya maksimal. Berdasarkan kenyataan dilapangan; sarana dan prasarana yang disediakan oleh pemerintah di Rumah Sakit Umum Daerah Bangka Selatan, Rumah Sakit Umum Daerah Pangkalpinang, Rumah Sakit Bhakti Timah Pangkalpinang untuk mengimplementasikan Program Pelayanan Jaminan Kesehatan Nasional-Badan Penyelenggara Jaminan Sosial Kesehatan sudah baik tetapi perlu diperhatikan dan diperbaiki lagi dengan segera.

Sarana dan prasana ini sangat berpengaruh terhadap Program Pelayanan Jaminan Kesehatan Nasional-Badan Penyelenggara Jaminan Sosial Kesehatan di Rumah Sakit Umum Daerah Bangka Selatan agar maksimal hasilnya. Sarana dan prasana yang dimiliki ke tiga rumah sakit tersebut masih sangat kurang dibandingkan jumlah pasien yang datang untuk berobat, hal ini sering kali terjadi, baik di Rumah Sakit Umum Daerah Bangka Selatan, Rumah Sakit Umum Daerah Pangkalpinang, Rumah Sakit Bhakti Timah Pangkalpinang sangat ruang rawat inap, maupun ruang rawat jalan, sehingga pasien tidak tertampung, apa lagi untuk kelas tiga bagi Program Pelayanan Jaminan Kesehatan Nasional-Badan Penyelenggara Jaminan Sosial Kesehatan, sering kali masyarakat mengeluh dan kecewa.

Di Rumah Sakit Umum Daerah Bangka Selatan pernah terjadi pasien yang masuk di kelas tiga hanya beralasan kasus tipis tanpa ada sperainya, ruangannya kotor begitu juga dengan dokter dan perawatnya hanya datang waktu si pasien masuk dan terakhir ketika si pasien sudah meninggal dunia itupun dipanggil oleh keluarganya untuk memastikan apakah 
betul-betul sudah meninggal dunia atau dalam keadaan koma. Selain itu jumlah mobil ambulannya ada lima buah tetapi tiga dalam keadaan rusak. Jadi cuma dua yang layak jalan, itupun kadang-kadang tidak ada di dalam tangkinya bahan bakar minyaknya. Hal yang miris sekali kadang-kadang tidak sopirnya, sampai ada kasus si pasien harus di bawa ke Pangkalpinang karena kekurangan alat medis di Rumah Sakit Umum Daerah Bangka Selatan dan keluarga si pasien mencari sopir ambulan ternyata di masuk kerja pada hari itu (bertepatan dengan hari Minggu) sampai 90 menit si pasien berada dalam mobil ambulan dengan keadaan tidak sadar, diinfus, ditemani perawat dan keluarga pasien, karena terlalu lama menunggu sopir akhirnya si pasien meninggal dunia dalam mobil ambulan tersebut. Akhirnya sopir tersebut diberhentikan dan hukum karena lalai dalam menjalankan tugasnya. Kasus ini terjadi tahun 2016 yang lalu.

Kasus lain juga terjadi di Rumah Sakit Umum Daerah Pangkalpinang si pasien yang sudah berusia 68 tahun dari desa Cambai-Bangka Tengah terkena penyakit jantung, batuk, sesak nafas, keluarga harus 90 menit karena tidak dapat ruang pengguna Program Pelayanan Jaminan Kesehatan Nasional-Badan Penyelenggara Jaminan Sosial Kesehatan kelas tiga (BPJS kelas III). Sampai keluarga gelisah melihat keadaan bapaknya dibiarkan begitu saja oleh petugas di rumah sakit tersebut, kemudian keluarganya menanyakan kepada saya pada waktu kebetulan ada keperluan di rumah sakit tersebut saya katakana lebih baik tidak menggunakan fasilitas BPJS kelas III pindahkan saja kelas II atau kelas I pasti ada ruangan saya katakana. Kasus ini terjadi pada Bulan Oktober 2017.

Kemudian kasus yang terjadi Rumah Sakit Bhakti Timah Pangkalpinang pada tanggal 6 Oktober 2017, setelah menjalani perawatan khusus bayi laki-laki yang dilahirkan oleh Rahayu (18 tahun) di dalam mobil akibat ditolaknya untuk merujuk ke Rumah Sakit Bhakti Timah Pangkalpinang menghembuskan nafas terakhirnya di dalam ruang incubator Rumah Sakit Bhakti Wara (9 Oktober 2017). Sebelum terjadi penolakan dengan keras alasan tidak ada ruang lagi untuk pasien karena telah penuh, dalih dari pihak Rumah Sakit Bhakti Timah, kemudian dialihkan ke Rumah Sakit Bhakti Wara, dan meninggal di dalam mobil di halaman parkir Rumah Sakit Bhakti Wara. Mendengar berita tersebut gubernur Erzaldi Rosman langsung memberikan ultimatum terhadap pihak rumah sakit yang menolak pasien karena melanggar Undang-Undang Kesehatan Nomor 36 Tahun 2009 pasal 32 ayat 2 dan bagi pimpinan fasilatas pelayanan kesehatan/ tenaga kesehatan yang melanggar pasal 32 ayat 2 itu akan dipenjara maksimal 2 tahun dan denda maksimal 200 jura (pasal 190 ayat 1 . Kalau 
benaar kejadiannya seperti itu, saya minta Komisi Kesehatan di Rumah Sakit tersebut melakukan evaluasi, tegas Erzaldi (Tabloid Hukum dan Kriminal 86, Edisi 74 halaman 8).

\section{Disposisi}

Disposisi atau sikap para pelaksana yang akan menimbulkan hambatan-hambatan nyata terhadap implementasi kebijakan jika personil yang ada tidak mampu menjalankan kebijakan sesuai tujuannya. Salah satu faktor yang dapat mempengaruhi efektivitas implementasi kebijakan pemerintah adalah sikap implementor itu sendiri. Jika para implementor itu setuju dengan bagian-bagian isi dari kebijakan, maka mereka akan melaksanakan dengan senang hati tetapi jika berbeda dengan pandangan pembuat kebijakan secara otomatis proses implementasi akan mengalami banyak masalah dan cenderung banyak yang gagal program kebijakan tersebut. Berdasarkan kenyataan di lapangan, implementasi Program Pelayanan Jaminan Kesehatan Nasional-Badan Penyelenggara Jaminan Sosial Kesehatan ini kurang maksimal hasilnya.

Hal ini disebabkan kurangnya kesadaran para implementor terhadap tugas yang mereka jalani sebagai abdi negara dan abdi dalam memberikan pelayanan kepada masyarakat, sehingga banyak masyarakat yang menerima Program Pelayanan Jaminan Kesehatan Nasional-Badan Penyelenggara Jaminan Sosial Kesehatan di Rumah Sakit Umum Daerah Bangka Selatan, Rumah Sakit Umum Daerah Pangkalpinang, Rumah Sakit Bhakti Timah Pangkalpinang merasa kecewa karena hasilnya belum memadai. Ada anggapan seolah-olah mereka yang menggunakan Program Pelayanan Jaminan Kesehatan NasionalBadan Penyelenggara Jaminan Sosial Kesehatan ini adalah gratis total, padahal para pasien telah membayar tiap bulan dipotong langsung dengan cara ikut dari kantor masing-masing tempat mereka bekerja, ataupun banyak masyarakat yang ikut BPJS mandiri.

\section{Struktur Birokrasi}

Struktur birokrasi bisa mempengaruhi keberhasilan atau terhambatnya implementasi kebijakan pemerintah. Kelemahan yang terjadi dalam struktur birokrasi menyebabkan tidak dapat terlaksananya, terealisasinya suatu kebijakan dengan baik. Struktur birokrasi yang tidak kondusif dapat menyebabkan sumber daya manusia (dokter, tenaga medis, perawat, bidan, dan tenaga kerja yang lainnya) tidak efektif dan bisa menghambat jalannya implementasi Program Pelayanan Jaminan Kesehatan NasionalBadan Penyelenggara Jaminan Sosial Kesehatan ini. Struktur birokrasi memang diperlukan dalam menjalankan kebijakan pemerintah. Struktur birokrasi yang ketat dan panjang tidak masalah asalkan tidak bertentangan dengan Undang-Undang Republik Indonesia Nomor 24 
Tahun 2011 dan Peraturan Menteri Kesehatan Republik Indonesia Nomor 28 Tahun 2014, yang berlaku dan bukan untuk menghambat, menghalangi pelaksanaan program kebijakan tersebut. Untuk itu struktur birokrasi harus memiliki Standar Operasional Prosedur (SOP) dan Fragmentasi. Standar Operasional Prosedur merupakan tuntunan internal akan kepastian waktu, sumber daya, serta kebutuhan penyeragaman kerja dalam organisasi yang kompleks dan luas. Dengan menggunakan Standar Operasional Prosedur, para implementor kebijakan Program Pelayanan Jaminan Kesehatan Nasional-Badan Penyelenggara Jaminan Sosial ini dapat mengoptimalkan waktu pelaksanaan dan berfungsi untuk menyeragamkan berbagai tindakan harus dilakukan pimpinan organisasi.

Berdasarkan kenyataan dilapangan bahwa prosedur implementasi Program Pelayanan Jaminan Kesehatan Nasional-Badan Penyelenggara Jaminan Sosial Kesehatan ini belum berjalan dengan baik dan sesuai dengan Undang-Undang Republik Indonesia Nomor 24 Tahun 2011 dan Peraturan Menteri Kesehatan Republik Indonesia Nomor 28 Tahun 2014. Sedangkan fragmentasi yang merupakan penyebaran tanggung jawab implementasi Program Pelayanan Jaminan Kesehatan Nasional-Badan Penyelenggara Jaminan Sosial Kesehatan di Rumah Sakit Umum Daerah Bangka Selatan, Rumah Sakit Umum Daerah Pangkalpinang, Rumah Sakit Bhakti Timah Pangkalpinang kepada beberapa badan yang berbeda sehingga memerlukan koordinasi.

Hal ini juga belum cukup bahkan cenderung jelak koordinasi yang dilakukan, dan terbukti banyak implementor tidak mengetahui dan mengerti bagaimana bentuk tanggung jawab koordinasi antar pihak pelaksana kebijakan pemerintah, masyarakat, Pemerintah Daerah Bangka Selatan, Pemerintah Daerah Pangkalpinang dan Pemerintah Pusat. Ketika ada kasus atau masalah yang terjadi tidak cukup dengan hanya minta maaf begitu saja tetapi harus ada tindakan dan solusi yang konkret agar tidak terjadi lagi di masa yang akan datang. Seperti kasus yang terjadi di Rumah Sakit Bhakti Timah Pangkalpinang yang menimpa Rahayu dan bayinya, dengan gampang Anggi Siahaan mewakili Managemen RSBT yang tergabung dalam PT. Rumah Sakit Bhakti Timah, mengatakan dengan dalih bahwa penolakan pasien lantaran penuh. Ia mengatakan pasien yang hendak melahirkan di RSBT diarahkan ke Rumah Sakit Ibu dan Anak Muhaya karena alasan keterbatasan kapasitas ruang kebidanan serta sumber daya manusia. Atas kejadian ini pihak Managemen Rumah Sakit Bhakti Timah Pangkalpinang (RSBT) minta maaf. Menurut data yang ada kondisi tersebut terjadi pagi hari. Kapasitas overload dari 15 ruangan ada 16 pasien ibu dan 9 anak bayi, ada 
prepare dari staf medis untuk 4 operasi dan 1 butuh penangan khusus, menurut Anggi Siahaan (Tabloid Hukum dan Kriminal 86, Edisi 74 halaman 8).

Pelayanan kesehatan dapat dianggap sebagai aspek penting dalam kebijakan sosial. Kesehatan merupakan faktor penentu bagi kesejahteraan sosial. Orang yang sejahtera bukan saja orang yang memiliki pendapatan atau rumah memadai. Melainkan pula orang yang sehat baik jasmani maupun rohani. Kesehatan adalah kondisi umum dari seseorang dalam semua aspek. Ini juga merupakan tingkat efisiensi fungsional dan/atau metabolisme organisme, sering implisit manusia.

Organisasi Kesehatan Dunia (WHO), pada tahun 1948 mendefinisikan kesehatan sebagai "suatu keadaan fisik, mental, dan sosial kesejahteraan dan bukan hanya ketiadaan penyakit atau kelemahan". Pada tahun 1986, WHO, dalam Piagam Ottawa untuk Promosi Kesehatan, mengatakan bahwa kesehatan adalah "sumber daya bagi kehidupan sehari-hari, bukan tujuan hidup Kesehatan adalah konsep positif menekankan sumber daya sosial dan pribadi, serta kemampuan fisik." Klasifikasi sistem seperti WHO Keluarga Klasifikasi Internasional (WHO-FIC), yang terdiri dari Klasifikasi Internasional Berfungsi, Cacat, dan Kesehatan (ICF) dan Klasifikasi Internasional Penyakit (ICD) juga menentukan kesehatan.

Secara keseluruhan kesehatan dicapai melalui kombinasi fisik, mental, dan kesejahteraan sosial, yang bersama-sama sering disebut sebagai Segitiga Kesehatan. Golongan masyarakat yang dianggap 'teranaktirikan' dalam hal jaminan kesehatan adalah mereka dari golongan masyarakat kecil dan pedagang. Dalam pelayanan kesehatan, masalah ini menjadi lebih pelik, berhubung dalam manajemen pelayanan kesehatan tidak saja terkait beberapa kelompok manusia, tetapi juga sifat yang khusus dari pelayanan kesehatan itu sendiri. Pada dasarnya kesehatan itu meliputi empat aspek, antara lain:

a. Kesehatan fisik terwujud apabila sesorang tidak merasa dan mengeluh sakit atau tidak adanya keluhan dan memang secara objektif tidak tampak sakit. Semua organ tubuh berfungsi normal atau tidak mengalami gangguan.

b. Kesehatan mental (jiwa) mencakup 3 komponen, yakni pikiran, emosional, dan spiritual.

1. Pikiran sehat tercermin dari cara berpikir atau jalan pikiran.

2. Emosional sehat tercermin dari kemampuan seseorang untuk mengekspresikan emosinya, misalnya takut, gembira, kuatir, sedih dan sebagainya.

3. Spiritual sehat tercermin dari cara seseorang dalam mengekspresikan rasa syukur, pujian, kepercayaan dan sebagainya terhadap sesuatu di luar alam fana ini, yakni Tuhan Yang Maha Kuasa. Misalnya sehat spiritual dapat dilihat dari praktik keagamaan seseorang. Dengan perkataan lain, sehat spiritual adalah keadaan dimana seseorang menjalankan ibadah dan semua aturan-aturan agama yang dianutnya. 
c. Kesehatan sosial terwujud apabila seseorang mampu berhubungan dengan orang lain atau kelompok lain secara baik, tanpa membedakan ras, suku, agama atau kepercayan, status sosial, ekonomi, politik, dan sebagainya, serta saling toleran dan menghargai.

c. Kesehatan dari aspek ekonomi terlihat bila seseorang (dewasa) produktif, dalam arti mempunyai kegiatan yang menghasilkan sesuatu yang dapat menyokong terhadap hidupnya sendiri atau keluarganya secara finansial.

\section{Kinerja Pegawai Negeri Sipil dalam Memberikan Pelayanan}

Kinerja merupakan kondisi yang harus diketahui dan diinformasikan kepada pihakpihak tertentu untuk mengetahui tingkat pencapaian hasil suatu instansi dihubungkan dengan visi yang diemban suatu organisasi serta mengetahui dampak positif dan negatif dari suatu kebijakan operasional yang diambil. Kinerja merupakan tingkat efisiensi dan efektivitas serta inovasi dalam pencapaian tujuan oleh pihak manajemen dan divisi-divisi yang ada dalam organisasi. Kinerja dikatakan baik dan sukses jika tujuan yang diinginkan dapat dicapai dengan baik. Kinerja juga dipandang sebagai fungsi dari interaksi antara kemampuan, motivasi dan kesempatan, sehingga kinerja seseorang dipengaruhi oleh kepuasaan kerja.

Kinerja adalah tingkat keberhasilan dalam melaksanakan tugas dan kemampuan untuk mencapai tujuan yang telah ditetapkan. Kinerja pada dasarnya adalah apa yang dilakukan atau tidak dilakukan karyawan. Kinerja adalah catatan hasil produksi pada fungsi pekerjaan yang spesifik atau aktivitas selama periode waktu tertentu. Dalam melakukan penilaian terhadap kinerja karyawan yang berdasarkan deskripsi perilaku yang spesifik.

Dapat disimpulkan bahwa kinerja adalah penampilan yang melakukan, menggambarkan dan menghasilkan sesuatu hal, baik yang bersifat fisik dan non fisik yang sesuai dengan petunjuk, fungsi dan tugasnya yang didasari oleh pengetahuan, sikap dan keterampilan. Setiap individu atau organisasi tertentu memiliki tujuan yang akan dicapai dengan menetapkan target atau sasaran. Keberhasilan individu atau organisasi dalam mencapai target atau sasaran tersebut merupakan kinerja.

Menurut Robbins yang menjadi ukuran kinerja pegawai mempertimbangkan hal-hal sebagai berikut: kemampuan, motivasi, kesempatan. Pertama, kemampuan adalah kapasitas seorang individu untuk mengerjakan berbagai tugas dalam suatu pekerjaan. Seorang pegawai negeri sipil harus mempunyai kemampuan dan kemahiran dalam melaksanakan tugas dan pekerjaannya. Dengan adanya kemampuan yang dimiliki akan meningkatkan prestasi kerja dalam organisasi tersebut. Kemampuan di sini terdiri dari tiga indikator yaitu kemampuan, kemahiran dan prestasi kerja pegawai. Seorang pegawai harus mempunyai 
kemampuan dan kemahiran dalam melaksanakan tugas dan pekerjaannya, dengan adanya kemampuan yang dimiliki akan meningkatkan prestasi kerja dalam organisasi tersebut. Dilihat dari kemampuan yang dimiliki oleh para pegawai negeri sipil untuk memberikan pelayanan Jaminan Kesehatan Nasional-Badan Penyelenggara Jaminan Sosial Kesehatan ini masih sangat kurang, hal ini bisa dinilai dari kinerja mereka dalam menyelesaikan berbagai pekerjaan maupun tugas yang menjadi kewajiban dan wewenangnya. Begitu juga dengan tingkat kemahiran yang mereka miliki dalam mengerjakan semua pekerjaan dan tugasnya, dapat dikatakan masih di bawah standar dan belum sesuai dengan harapan semua pihak. Sedangkan prestasi kerja pegawai bisa dikatakan masih sangat kurang, karena mereka belum bisa menunjukkan produktivitas kerjanya baik menyangkut kualitas maupun kuantitas terhadap target yang ingin dicapai sesuai tujuan, visi, misi dan program kerja tentang pelayanan Jaminan Kesehatan Nasional-Badan Penyelenggara Jaminan Sosial Kesehatan ini.

Hal ini mengindikasikan bahwa dimensi kemampuan yang meliputi kemampuan, kemahiran dan prestasi kerja pegawai, ternyata kurangnya kemampuan pegawai negeri sipil belum mampu bekerja dengan baik dan cepat, kurang memilik keahlian dan ketrampilan dalam menyelesaikan pekerjaannya, untuk itu perlu ditingkatkan lagi dalam rangka usaha mencapai kinerja pegawai negeri sipil untuk memberikan pelayanan Jaminan Kesehatan Nasional-Badan Penyelenggara Jaminan Sosial Kesehatan di Rumah Sakit Umum Daerah Bangka Selatan, Rumah Sakit Umum Daerah Pangkalpinang, Rumah Sakit Bhakti Timah Pangkalpinang.

Kedua, Motivasi adalah keadaan untuk mengeluarkan tingkat upaya yang tinggi kearah tujuan-tujuan organisasi yang dikoordinasikan oleh kemampuan upaya itu memenuhi kebutuhan individu. Motivasi merupakan dorongan atau kehendak yang menyebabkan seseorang bertindak atau berbuat sesuatu untuk mencapai suatu tujuan. Motivasi memiliki tiga unsur yang paling berkaitan satu dengan yang lain terdiri dari kebutuhan, dorongan dan tujuan.

Kebutuhan ini merupakan hal yang mendasar, misalnya kebutuhan fisik (dasar) atau psycological needs, keamanan (security), sosial (social), penghargaan (esteem), pengakuan (self actualization). Berbagai kebutuhan inilah yang menjadi motivasi bagi pegawai negeri sipil dalam melakukan berbagai pekerjaan dengan lebih baik. Motivasi itu datang langsung dari atasan, lingkungan kerja, teman-teman kerja sekantor, dan dari dalam dirinya sendiri. Motivasi dari atasan (pimpinan), lingkungan kerja, teman-teman kerja sekantor inilah yang 
belum kelihatan dan dirasakan dengan maksimal oleh pegawai negeri sipil untuk memberikan pelayanan Jaminan Kesehatan Nasional-Badan Penyelenggara Jaminan Sosial Kesehatan ini untuk meningkatkan kinerjanya. Begitu juga dengan dorongan untuk melakukan pekerjaan agar lebih kreatif, inovasi sehingga hasilnya lebih efektif dan efisien, serta memiliki kualitas yang memadai.

Dorongan untuk melakukan pekerjaan dengan tepat, cepat, terbuka dan mudah dari pimpinan (atasan) belum kelihatan hasilnya. Karena dorongan yang baik itu bukan hanya ucapan (teori saja) tetapi harus berupa tindakan riil sebagai contoh dari pimpinan untuk menyelesaikan pekerjaan atau tugas sesuai peraturan perundang-undang yang berlaku. Hal ini belum dilakukan oleh pimpinan bagi pegawai negeri sipil untuk memberikan pelayanan Jaminan Kesehatan Nasional-Badan Penyelenggara Jaminan Sosial Kesehatan ini untuk meningkatkan kinerjanya. Sedangkan tujuan adalah target awal dari organisasi yang telah ditetapkan terlebih dahulu. Banyak pekerjaan yang belum bisa diselesaikan tepat dalam waktu yang telah ditentukan sesuai targetnya. Hal ini disebabkan kurangnya motivasi, kebutuhan, dan dorongan yang diberikan oleh pimpinan bagi pegawai negeri sipil untuk memberikan pelayanan Jaminan Kesehatan Nasional-Badan Penyelenggara Jaminan Sosial Kesehatan di Rumah Sakit Umum Daerah Bangka Selatan, Rumah Sakit Umum Daerah Pangkalpinang, Rumah Sakit Bhakti Timah Pangkalpinang untuk memperbaiki dan meningkatkan kinerjanya.

Ketiga, kesempatan adalah kesempatan menunjukkan meskipun seseorang individu mungkin bersedia dan mampu, mungkin ada rintangan yang mengendalikan. Adanya kesempatan bagi pegawai untuk mengembangkan keahlian dan ketrampilan. Kesempatan adalah kepercayaan yang dimiliki seorang pegawai untuk melakukan pekerjaan dan tugas sesuai dengan kewenangan yang telah diberikan kepadanya, akan tetapi masih banyak kesempatan itu disia-siakan oleh pegawai, tidak bersedia melakukannya dengan alasan tidak adanya kemampuan. Ada juga yang bersedia dan mampu untuk melakukannya tetapi tidak memiliki kesempatan. Ini semua adalah rintangan.

Hal inilah yang perlu dicari dan diberi solusinya oleh pimpinan agar semua pekerjaan dan tugas itu bisa dilakukan dengan baik oleh pegawai atau orang yang betul-betul memiliki kompetensi dan bertanggung jawab atas kewajibannya sesuai peraturan perundangundangan yang berlaku. Berdasarkan kenyataannya, hal ini belum dilakukan sepenuhnya oleh pimpinan bagi pegawai negeri sipil untuk memberikan pelayanan Jaminan Kesehatan Nasional-Badan Penyelenggara Jaminan Sosial Kesehatan di Rumah Sakit Umum Daerah 
Bangka Selatan, Rumah Sakit Umum Daerah Pangkalpinang, Rumah Sakit Bhakti Timah Pangkalpinang untuk meningkatkan kinerjanya sesuai harapan publik. Ini semua adalah kesempatan bagi pemimpin, para pegawai negeri sipil untuk bersama-sama memperbaiki citra kinerjanya dalam memberikan pelayanan yang maksimal dan berkualitas agar masyarakat bisa menikmatinya dengan puas. Masayarakat juga harus bisa memberikan masukan, solusi, kritikan dan evaluasi demi kebaikan bersama.

\section{Penutup}

Implementasi kebijakan pemerintah dalam mengoptimalisasikan kinerja pegawai negeri sipil untuk memberikan pelayanan Jaminan Kesehatan Nasional-Badan Penyelenggara Jaminan Sosial Kesehatan di Rumah Sakit Umum Daerah Bangka Selatan, Rumah Sakit Umum Daerah Pangkalpinang, Rumah Sakit Bhakti Timah Pangkalpinang sangat dipengaruhi oleh faktor komunikasi, sumber daya, disposisi, dan struktur birokrasi. Hasil implementasi kebijakan pemerintah tentangn Jaminan Kesehatan Nasional-Badan Penyelenggara Jaminan Sosial Kesehatan di Rumah Sakit Umum Daerah Bangka Selatan, Rumah Sakit Umum Daerah Pangkalpinang, Rumah Sakit Bhakti Timah Pangkalpinang belum maksimal dan perlu diperbaiki dengan segera.

Sedangkan kinerja pegawai negeri sipil untuk memberikan pelayanan Jaminan Kesehatan Nasional-Badan Penyelenggara Jaminan Sosial Kesehatan di Rumah Sakit Umum Daerah Bangka Selatan, Rumah Sakit Umum Daerah Pangkalpinang, Rumah Sakit Bhakti Timah Pangkalpinang para pegawainya belum maksimal memiliki kemampuan, motivasi, dan melaksanakan kesempatan dengan baik. Untuk meningkatkan kinerja yang baik seluruh pegawai tanpa terkecuali harus mampu berkomunikas dengan baik sehingga tugas atau pekerjaan yang dilaksanakan sesuai dengan fungsi dan kewenangannya dapat bermanfaat dan bernilai guna bagi masyarakat luas. 


\section{DAFTAR PUSTAKA}

Arif, Sjofyan, Mirrian, dkk., Manajemen Pemerintahan, Jakarta: Universitas Terbuka, 2008.

Djopari, J.R.G., Kebijakan Pemerintahan, Jakarta: Universitas Terbuka, 2009.

Edwards III, George, C. Implementasi Kebijakan Publik: Transpormasi Pikiran, Yogyakarta: Lukman Opset, 2003.

Islamy, M. Irfan, Prinsip-Prinsip Perumusan Kebijaksanaan Negara, Jakarta: PT. Bumi Aksara, 2004.

Lukman, Sampara. Manajemen Kualitas Pelayanan, Jakarta: STIA LAN Press, 2003.

Peraturan Menteri Kesehatan Republik Indonesia Nomor 28 Tahun 2014 Tentang Pedoman Pelaksanaan Program Jaminan Kesehatan Nasional.

Prawirosentono, Suyadi, Kebijakan Kinerja Karyawan, Yogyakarta: BPFE, 1999.

Robbins, Stephen, P., Perilaku Organisasi, Jilid 1 dan 2, trans. by Tim Indeks. Jakarta: PT. Indeks Kelompok Gramedia, 2008.

Samsudin, Sadili, Manajemen Sumber Daya Manusia, Bandung: Pustaka Setia, 2005.

Sugiarto, Demensi Pelayanan Sehari-hari: Kinerja Pemerintahan= Indikator yang dilupakan, Jakarta: LAN, 2003.

Triguno, Budaya Kerja, Menciptakan Lingkungan yang Kondusif Untuk Meningkatkan Produktifitas Kerja, Jakarta: Gulgen Trapon Press, 2002.

Undang-Undang Republik Indonesia Nomor 24 Tahun 2011 Tentang Badan Penyelenggara Jaminan Sosial.

Undang-Undang Nomor 43 Tahun 1999 Tentang Pokok-Pokok Kepegawaian.

Widodo, Joko, Analisis Kebijakan Publik: Konsep dan Aplikasi Analisis Proses Kebijakan Publik, Malang: Bayumedia Publishing, 2010.

Winarno, Budi. 2004. Teori dan Proses Kebijakan Publik. Yogyakarta: Media Pressindo. 